REPORTS

The Alma River Intertidal Delta in the Bay of Fundy at Alma, N.B.*

S. IKRAMUDDIN ALI,

Deputy Director, Geological Survey of Pakistan, Quetta

and D. J. C. LAMING,

Department of Geology, University of New Brunswick, Fredericton, N.B.

The Alma River delta is located at $45^{\circ} 36^{\prime} \mathrm{N}, 64^{\circ} 57^{\prime} \mathrm{W}$, close to Fundy National Park on the north shore of the Bay of Fundy. The river has a short steep course in the nearby Caledonian Mountains, and though its flow is not large it is subject to occasional floods which influence the morphology of the delta. The tidal range is high, averaging 30 feet at Alma, and a strong outflow from the small estuary of the river occurs on the ebb tide; as the tide falls this outflow follows an established channel across the delta fan. The intertidal portion of the delta occupies about 0.3 square miles.

The major delta element is a fan composed of poorly sorted gravel, coarsest at its apex at the river mouth, and with scattered boulders. This continues seawards an unknown distance beyond the low tide mark, and is covered with radial channels and channel scars, many partly infilled. The river channel followed a straight course across the fan in 1953, but by 1962 (both are dates of air photographs) had virtually abandoned it and adopted a more southerly braided course at the foot of the beach slope. The beach consists mainly of a veneer of sand and gravel, the gravel commonly forming beach cusps; it merges into; a berm crest backed by muddy tidal marshes where cliffs are absent.

Gravel bars built by wave action are prominent intertidal features situated on the outer part of the fan, and are present also below low tide level. They are up to 14 feet in height, with steeper side-slopes facing shoreward; their outline is curved or geniculate, and appears to be controlled by directions of wave approach and probably by tidal currents also. Fine grained sediments are deposited in the troughs between the bars.

The polymict character of the gravels indicates that the source of the fan material was glacial drift which occupied the floors of the valleys around Alma. The fan itself is probably, in part, merely a winnowed "lag deposit" of in situ glacial drift, reworked by wave and current action; though undoubtedly most of the material has been subject to at least some marine transportation. Mean size, sorting, sphericity and percentage of spheroidal pebbles all indicate a net seaward transport. There is also evidence of transport from south west to north east during the flood tide, though this conclusion has yet to be tested. The gravel bars are derived from the fan by wave action, and consequently have

*Manuscript received 13 September 1965 


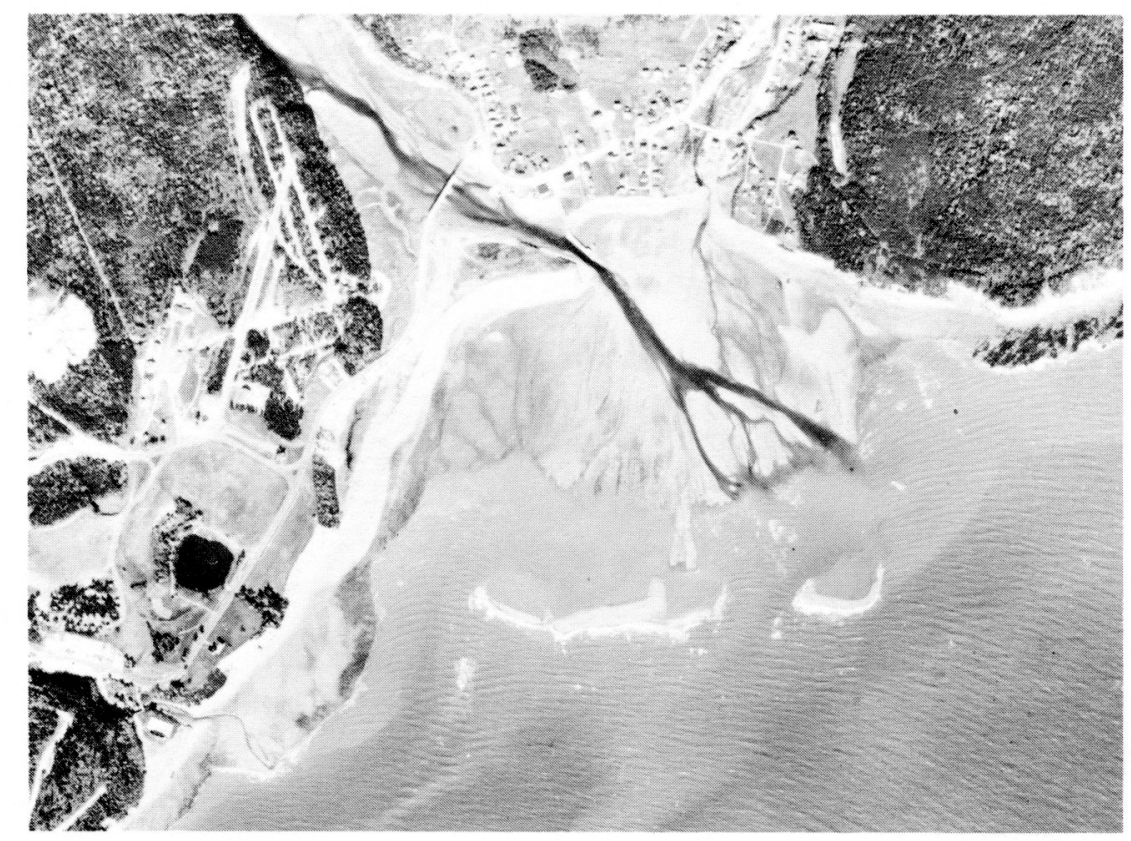

Figure 1. Alma River delta near low tide: aerial photograph, 1959. Note the straight distributary channels, the abandoned distributary tongue, and the geniculate bars with new deposition opposite the torigue. A bedrock abrasion platform is seen at extreme right beneath cliffs. North is at the top of the photograph, and the width of the area shown is about 7000 feet.

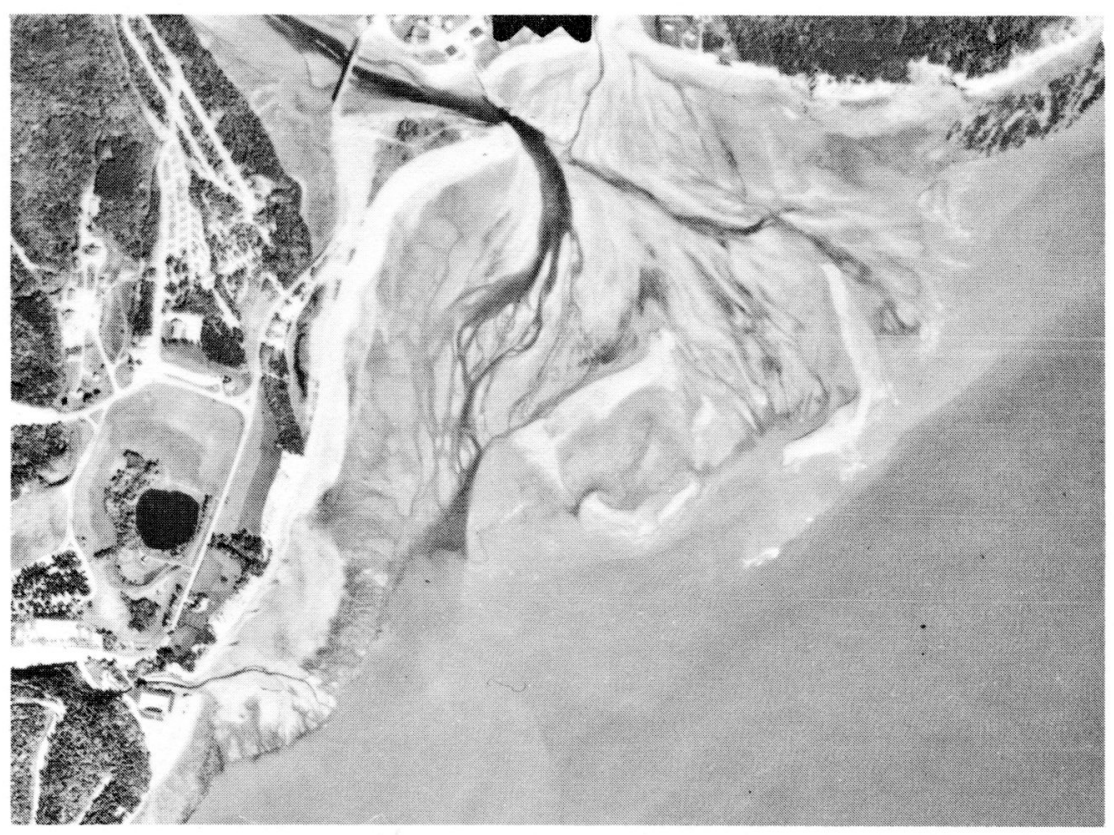

Figure 2. Alma River delta at low tide: aerial photograph, 1962. Note the changed courses for the main distributary and the side stream (Cleveland Brook); the growth of bars across the former distributary mouths, and the presence of a new inner bar. Width of area shown about 6000 feet. 
better sorting; they are subject to size variations that indicate transport in a south-westerly direction, presumably on the ebb tide. Interesting sedimentary structures are observed on the bar flanks and in the troughs as a result of water seepage from the bar.

The majority of this study comprised an M.Sc. thesis by ALI (1964) under the supervision of the senior author. Work is proceeding further to evaluate the conclusions reached, and will mainly concern the relationship of processes to sedimentary trends. More detail of the latter will be derived from further sampling and analysis, making comparisons with the original samples collected in 1963. Aerial photographs taken in 1953 and 1962 will be supplemented by a series taken at varying states of tide using a small aircraft, and an attempt will be made to map the surface tidal currents using markers dropped from the air. A detailed sounding survey will be made of the offshore portion of the delta to delineate the submerged bars and to look for any sea floor channels likely to be connected with turbid river-flood currents. The internal structure of the exposed bars will be examined between tides using earthmoving machinery and/or student labour. It is hoped that sparker traversing will also be arranged.

\title{
Reference cited
}

ALI, S. IKRAMUDDIN, 1964, Study of Recent sediments of the beach and delta at the mouth of Alma River (Bay of Fundy): unpublished M.Sç. thesis, University of New Brunswick.

\author{
Structural Studies in Paleozoic Rocks, \\ Nova Scotia and Gaspé \\ By W.K. FYSON \\ University of Ottawa, Ottawa, Ont.
}

The coastlines of Gaspé and Nova Scotia provide some excellently exposed sections of deformed Paleozoic rocks. In contrast, inland, apart from along a few streams, surficial deposits and bush effectively mask most of the Paleozoic backbone of the two peninsulas. The longterm projects of obtaining general histories of deformation have thus depended first on detailed structural studies of the coastal areas, and then, with the fragments of information from elsewhere, a great deal of imagination and extrapolation.

W.K. FYSON is studying the structures in Nova Scotia in both Carboniferous and pre-Carboniferous rocks (1964a, 1964b, 1966, inpress, and with BOUCOT et al in ms.), and Ph.D. student A.H. SIKANDER is concerned with the lower Palaeozoic rocks near Matane, Québec. They have been supported by the NATIONAL ADVISORY COMMITTEE of the GEOLOGICAL SURVEY OF CANADA, and have been greatly helped by the many recently published maps of the Geologica1 Survey of Canada and the QUEBEC DEPARTMENT OF MINES. 